\title{
Issues of shaping the students' professional and terminological competence in science area of expertise in the sustainable development era
}

\author{
Olena Lavrentieva ${ }^{1, *}$, Victoria Pererva ${ }^{1}$, Oleksandr Krupskyi $^{2}$, Igor Britchenko ${ }^{3}$, and Sardar Shabanov ${ }^{4}$ \\ ${ }^{1}$ Kryvyi Rih State Pedagogical University, 54 Gagarin Ave., Kryvyi Rih, 50086, Ukraine \\ ${ }^{2}$ Oles Honchar Dnipro National University, 35 Vladimir Mossakovsky Str., 49000 Dnipro, Ukraine \\ ${ }^{3}$ State University of Applied Sciences named prof. Stanislaw Tarnowski, 50 Sienkiewicza Str., Tarnobrzeg, 39400, Poland \\ ${ }^{4}$ Azerbaijan State University of Economics (UNEC), 6 Istiqlaliyyat Str., Baku, AZ1001, Azerbaijan
}

\begin{abstract}
The paper deals with the problem of future biology teachers' vocational preparation process and shaping in them of those capacities that contribute to the conservation and enhancement of our planet's biodiversity as a reflection of the leading sustainable development goals of society. Such personality traits are viewed through the prism of forming the future biology teachers' professional and terminological competence. The main aspects and categories that characterize the professional and terminological competence of future biology teachers, including terminology, nomenclature, term, nomen and term element, have been explained. The criteria and stages of shaping the future biology teachers' professional and terminological competence during the vocational training process have been fixed. Methods, techniques, technologies, guiding principles and forms of staged work on the forming of an active terminological dictionary of students have been described and specified. The content of the distant special course "Latin. Botanical Terminology", which provides training for future teachers to study the professional subjects and to understand of international scientific terminology, has been presented. It is concluded that the proper level of formation of the future biology teachers' professional and terminological competence will eventually ensure the qualitative preparation of pupils for life in a sustainable development era.
\end{abstract}

\section{Introduction}

Ukraine, among other countries, has pledged to achieve the 17 Sustainable Development Goals by 2030 to fight poverty, hunger and climate change and ensure well-being and prosperity for all segments of the population. In 2015, the General Assembly of the United Nations formulated the following Sustainable Development Goals, namely:

The Goals 14. Conserve and sustainably use the oceans, seas and marine resources for sustainable development.

The Goals 15. Protect, restore and promote sustainable use of terrestrial ecosystems, sustainably manage forests, combat desertification, and halt and reverse land degradation and halt biodiversity loss.

In this connection, biodiversity conservation is one of the most important components of Ukraine's state environmental policy. The biodiversity creates a safe environment for human life and health providing the population with food, medicine and raw materials for industry. It also supports the functioning of ecosystems including the circulation and purification of natural waters, soil conservation and climate stability. Ukraine, accounting for only $6 \%$ of Europe's total area, owns $35 \%$ its biodiversity [1].

The biodiversity conservation is one of the key components of a sustainable development strategy society and countries' environmental policy of the world and the EU. Thus, it's necessary to create a clear and effective system of formation of population's ecological culture and to prepare for this aim the qualified specialists in the biology area of expertise [2].

Today, in the environmental education and upbringing scope, the problem of the mismatch of young people's environmental knowledge to their behavior in nature is current importance. According to the Biological Diversity Conservation Concept of Ukraine, “... environmental knowledge should become a mandatory qualification requirement for all officials whose activities are related to the use of natural resources or to affect the environment" [3]. That is why the preparation of the future science teacher, who possesses the conceptual apparatus, terminology and nomenclature of living organisms, becomes relevant.

At the same time, it should be noted that modern higher education is oriented at finding methodical ways of organizing the educational process and directed at training a competent specialist that ready for further professional and communication activities. The earnest of success of specialists in the modern labor market and to ensure their competitiveness in the sustainable development era is knowledge of professional terminology. The well-formed

\footnotetext{
* Corresponding author: helav68@gmail.com
} 
professional and terminological competence of future biology teachers reflects their ability to understand professional phenomena and concepts, as well as the existing level of their professional language culture.

The purpose of the study is to identify the nature and role of terminological and nomenclature units in the system of future biology teachers' subject knowledge, moreover to develop a procedure for the formation of professional and terminological competence of future biology teachers who are able to perform the main professional functions in the sustainable development era.

\section{Materials and methods}

The presented study broadly analyzes the scientific works concerning the problems of shaping the future specialists' terminological competence (Halyna P. Bondarenko, Tetiana O. Butenko [4], Oksana Ye. Hrydzhuk [5], Tetiana A. Denyshchych, Emiliia I. Ohar, Larysa L. Rytikova, Tetiana V. Symonenko, Tetiana V. Stasiuk and others), as well as of their professional and terminological competence (Liliia V. Baranovska [6], Valentyna D. Borshchovetska, Nataliia S. Borodina, Lesia V. Viktorova, Iryna V. Vlasiuk, Volodymyr O. Domin [7] and others). Source analysis shows the most authors investigate the role and correlation between professional nomenclature and terminology in the humanities study context, and mainly during preparation of the students of language specialties.

At the same time the terminological system and professional and terminological competence in science area of expertise that formed in the students are essential for the sustainable development of society, in particular in the biodiversity conservation context. Tetiana L. Andriienko-Maliuk, Anna Y. Aleksandrova, Oksana O. Veklych [8], Olena V. Vrublevska, Lidiia S. Hryniv [9], Yurii M. Hryshchenko, Petro I. Haman, Leonid H. Melnyk, Ihor M. Syniakevych [10], Anatolii Ya. Sokhnych and others emphasize on this fact in their works.

It should take into account, the problem of biodiversity conservation is widely covered in the researches of domestic and foreign scientists, in particular Tetiana L. Andriienko-Maliuk, Anna Y. Aleksandrova, Oksana O. Veklych [8], Olena V. Vrublevska, Lidiia S. Hryniv [9], Yurii M. Hryshchenko, Petro I. Haman, Leonid H. Melnyk, Ihor M. Syniakevych [10], Anatolii Ya. Sokhnych and others. These works mostly study maintaining the ecological status of ecosystems. Serhii M. Bobylev, Henadii O. Motkin, Oleksandr S. Tulupov [11], Watson N. Dudley, Alexander N. James, Marc Hokungs, Stefano Pagiola and others investigate the economic aspects of biodiversity conservation.

It is known, any term functions in the environment of the nomen corresponding to it. The relation between the concepts "term" and "nomen" is still debatable. For the first time the issues of their delineation were raised in the researches of Hryhorii O. Vynokur and further developed in the works of Arkadii V. Lemov [12], Volodymyr M. Leichyk [13], Oleksandr I. Moiseiev [14], Hustav H. Shpet and others [15]. We assume that mastering the professional terminosystem by students is an interdependent process of studying by them binary nomenclature. For future biologists the professional terms are usually of Greek-Latin origin. Therefore, if biology teachers know the term elements, principles of word formation they can understand and correctly use of terms in professional speech.

Despite the elaboration of the problem of scientific terminology and terminosystem, the issue of the relation between nomenclature and terminology in the forming of the future biology teachers' terminosystem still remain out of the researchers' attention just like ways and means of shaping of the professional and terminological competence during the vocational training process.

Thus, in this paper, on the basis of the primary sources' analysis, through their generalization, concretization and interpolation, the methodology of forming professional and terminological competence in the future biology teachers will be modeled.

\section{Theoretical background}

Scientific terminology is the highest manifestation of human thought, the main structural element of the refinement and standardization of the language of a particular branch. The "term" is a word or phrase that means a clearly defined special concept of any field of science, technology, art, public life, etc. [16, p. 76]. Terms are used in the process of knowing and mastering scientific and professional objects and relations between them [17, p. 4-10].

While the analysis of terms by students, the priority is the structural-and-cognitive aspect, which consists in mastering by them the terminoelements. In fact, because biological terminology has Latin roots it is necessary to study semantics and etymology of the terminological elements of Greek-Latin origin. Evidently that on the basis of a capacious system of terminoelements, it is possible to form an individual active terminological dictionary of a future specialists, that is the core of their professional and terminological competence.

In our previous researches we defined the professional and terminological competence as a formed specialists' ability to correctly and appropriately use professional terms in their professional activity; as well as that is the set of acquired skills of oral and written language and the experience gained during the study of professional oriented subjects [18].

Among the criteria for the formation of future specialists' professional and terminological competence are the following [19]:

- the volume of professional terminology knowledge and the quality of professional speaking;

- the motivation in studying of professional terminology, the awareness of importance and necessity its using in the future profession;

- the efficiency in the utilize of professional terminology, the ability to use it while doing of own duties;

- the vocational approach in choosing language tools to explain processes and natural phenomena; 
- the skills to use professional terminology in the process of establishing communication relations, and awareness of the readiness to utilize it guided by personal traits [20, p. 17].

The forming of future biology teachers' professional and terminological competence is carried out in stages. The purpose and objectives of each of the steps are put forward with the focus on the development of a stable professional terminosystem via a students' active individual terminological thesaurus.

The reproductive (preparatory) stage (I course) is directly related to the adaptation of students to teaching at a pedagogical university, the development of scientific and cognitive interests and ideas about the structure of terms, etymology and semantics of basic terminoelements. The reproductive stage includes a diagnostic module, a module of general theoretical and scientific training of students, a module of methodological training, during which lay the foundations of mastering the scientific terminology by future teachers.

At the practical-methodological stage (II-III courses), in the conditions of interaction instructional work with the course of field practices, students practically master and consolidate components of professional and terminological competence.

Activity-creative (final) stage (IV course) includes production practice, performance of qualification works. At this stage, the results of students' educational activities integrate into the content-information, operationalactivity and personal levels, and the content of professional and terminological competence is made adjust and deepen.

Next, we look at the main aspects and categories that characterize the professional and terminological competence of future biology teachers and the main directions and tools its shaping.

\section{Didactical support of shaping the students' professional and terminological competence}

\subsection{Developing the content of the terminosystem and nomenclature key concepts}

Let's consider the relation between nomenclature and terminology. A terminosystem is a system of science terms containing a plurality of interrelated elements that constitute a stable unity. Nomenclature is a set of special terms-and-names used in this scientific field; the names of typical objects of this science (as opposed to terminology that include the designation of abstract concepts and categories) [21]. Unlike the terms, referring to certain abstract concepts and categories, the nomenclature is a certain inventory system of the science.

In particular, Grigoriy O. Vinokur points out following "as to nomenclature, this term, in contrast to terminology, should be understood as a system of absolutely abstract and conventional symbols, the sole purpose of which is to give, from a practical viewpoint, the most handy means of marking objects or things without direct connection with the need using of theoretical thinking". The terminosystem unit is the term and the nomenclature unit is the nomen [15].

In the heart of the distinction between the concepts "term" and "nomen" is taken their specific-and-subject or generalized conceptual relation. According to O. Moiseyev, this fact caused by the difference between "conceptual" and "substantive" terminology, that is, designations that more clearly reflect one's own conceptual orientation (i.e. the terms) or subject orientation (the nomens) [15].

There are three types of nominative units [20], such as: 1) nomenclature words, which mainly express single concepts and contain information about one object of reality and make subject relations; 2) industrial engineering terms expressing the general concepts and reflect a whole class of homogeneous objects and actualize the subject interrelationship; 3) scientific terms expressing general concepts and make conceptual relations (see Fig. 1). However, such a division of nominative units is rather conditional.

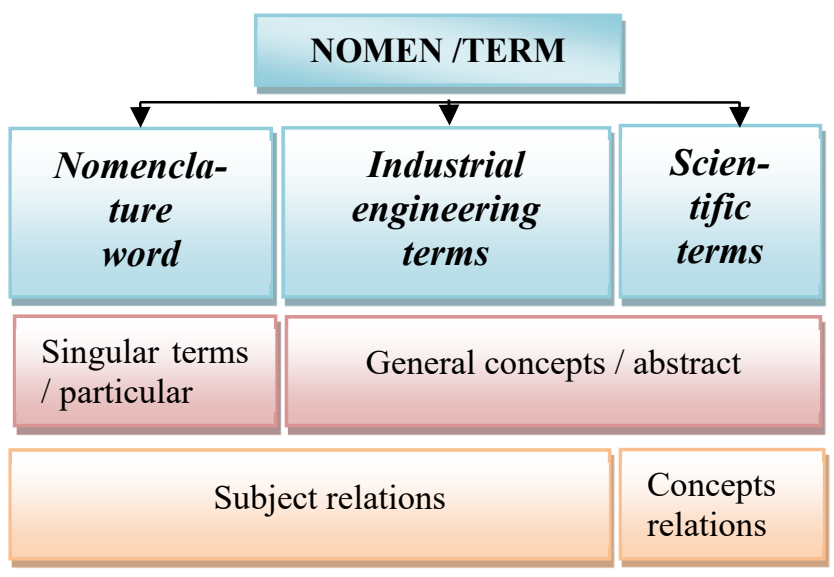

Fig. 1. Correlation between terms and nomens.

Thus, terminology considers nomenclature units as special types of terms that relate to individual concepts and actualize subject relations [22]. The peculiarity of the term, that distinguishes it from a word or a nomen, is its inseparable connection with a certain concept. What's more, a term carries out two functions: it names the subject and reflects the concept's content essential signs.

There are also differences in terminosystem and nomenclature one. The terms combine into a complex branching system (network) with hierarchical relations, and the nomens unite in rows that can "grow into" a rather simplified system. The nomenclature is accordingly defined as a component of the terminosystem or similar to it, but somewhat simplified.

The biological nomenclature is represented by nomens that correspond to the levels of the conditional division of the organic world into taxa such as species and superspecies. Species names can also be called The Binomen [23] because they consist of generic and species organism names, as for example: Couch Grass - Elytrigia repens $L$. The nomenclature ensures the uniqueness of the nomen that is the basis of biological research including study of biodiversity [24]. 
Among the biological nomens it can be single out phytonomens, zoonomens, myconomens, which are respectively a nomenclature of plant, animal organisms and fungi. There are quite a few terms in the literature that are used to refer to vegetal and animal world. Given that the nomenclature includes nomens, it is more appropriate to utilize phyto-, zoo-, myconomens in the professional terminosystem and to use a term, as for instance, "phytonomen" rather than "phytonym".

Apparently nomenclature is part of biological terminology, but so to speak specific. The term elements are common to terminology and nomenclature (see Fig. 2).

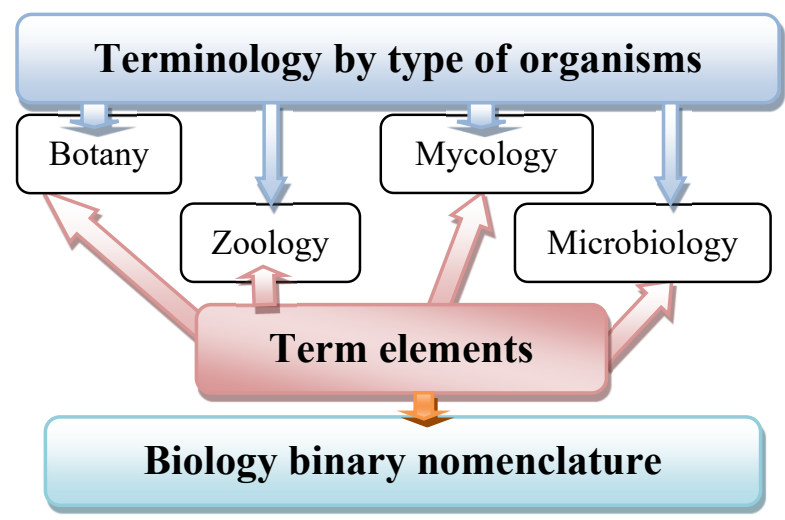

Fig. 2. Biology terminology and nomenclature in the system of professional knowledge.

In view of the above, it becomes clear that the future biology teachers should be able to properly speak the profession language, understand and use binary nomenclature in practice, have a high level of professional and terminological competence. This will, in the end, contribute to the conservation and enhancement of biodiversity and the achievement of sustainable development goals of society.

\subsection{Methodical support of shaping of students' professional and terminological competence}

The terminology mastering process has own peculiarities and complexities. In the first stages of studying the professional oriented subjects, students accumulate set of terms, which are often unsystematic and disparate. Practical experience shows it is only through purposeful work on the concepts' content that students can remember the terms profoundly. New terms are being introduced during the learning of concepts in course of teaching the study material, discussion or explanation, demonstration of nature objects or images, laboratory work, practical classes, excursions, and whatever. It is important for the same terms to be used in different learning situations, to be manifested in the direct observation of natural (or virtual) living nature objects [25, p.186-187].

Ivan. V. Moroz distinguishes the following methods and techniques of terminological work:

- Drawing of anatomical and morphological texture and structural units.

- Putting in a term during the explanation, recording with the following verbal or written interpretation, creating the special terminological dictionaries.

- Repeating articulation of term to train correct pronunciation.

- Determining the term's etymology and its translation into the native language.

- Clarifying the semantics and content of the term.

- Using of analytical and synthetic techniques that allow to disclosure etymology of concepts forming the term.

- The comparison method realization.

- Filling of parametric and resumptive tables, drawing up the word-logical schemes

- Making correlation of term and concept through techniques of underlining, selection, and grouping [25, p. 184].

Natalia A. Menchynska [26] believes there are two important stages in the terminology mastering process; these are macrogenesis and microgenesis. Throughout definition of concepts (in microgenesis) students carry out a logical operation, the essence of which is to disclose the meaning of the concept. During macrogenesis the concept enrich by theoretical notions, facts, methods and language of science; its scope and content expand in the implementation of interdisciplinary relations process. Therefore, mastery of scientific terminology depends on the level of formedness the students' skills to classify, summarize, find relationships, use facts as arguments in the course of proof, build and decipher models, do experiments, solve exploratory tasks.

Let's stay on a complex of didactic methods and means aimed at shaping terms and nomens which actually actualize during both the classroom work and independent work of future biology teachers. The didactic support of shaping of future biology teachers' professional and terminological competence is summarized in the scheme of Fig. 3.

A significant fundamental of shaping of the professional and terminological competence is students' active individual terminological thesaurus which creates on the base of mastering by the vocational terminology system. It should take into account that the terms' systematization into the terminosystem requires a creative and active approach, and implements with use of wellknown classroom forms of work as well as extracurricular and distant kind ones.

During independent work the conditions for thorough mastering of professional terminology by students are created. Independent work with a textbook or vocabulary allows systematize terminological knowledge and consists in the compilation of a glossary on a specific topic or module, as well as an individual terminological dictionary in a particular subject. Work with microproducts, models and dummies enables a visualization of the study material. Such independent work can be done both in real and virtual environment (digital photos of microscopic tissues' structure, 3-D digital models of structure of organs and systems, etc.). The advantages of virtual models over plane graphical images are their volume, expanding their scope to objects where the study of the topography of parts, their relative distribution and subordination are important. 


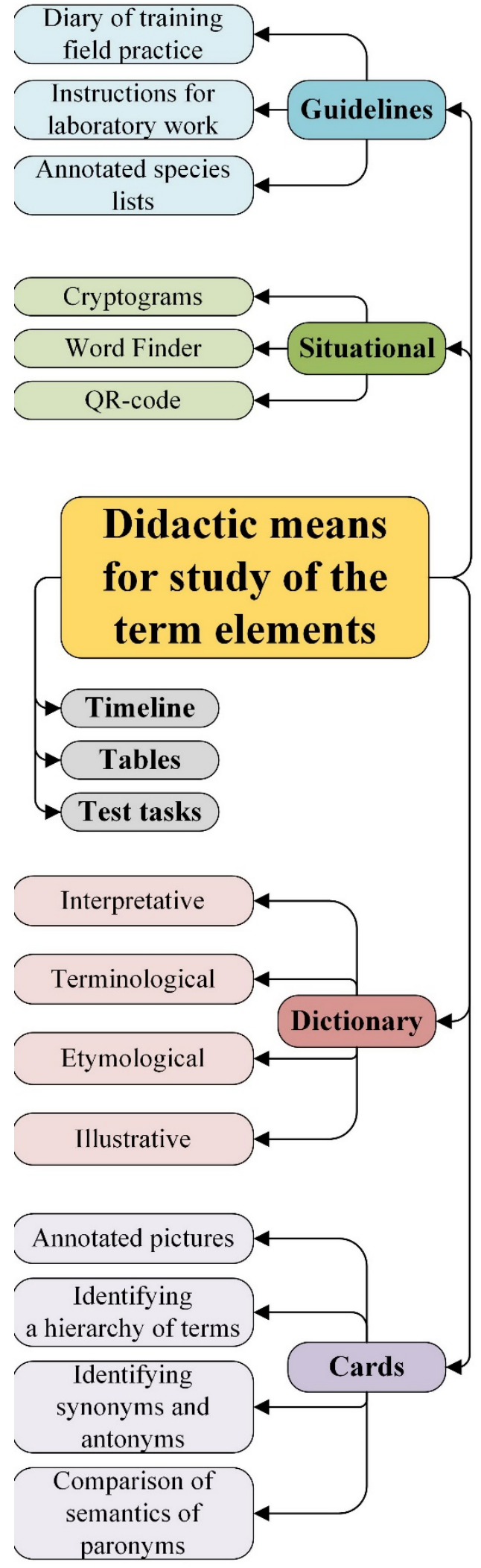

Fig. 3. The didactic means of shaping of future biology teachers' professional and terminological competence.

Terminological work with natural objects ensures the formation of correct ideas about the laws of the functioning of living organisms and nature phenomena. The biological terminology elaboration occurs during work with herbariums, various biological collections (seeds, fruits, skeletons, etc.), including virtual and digitized ones [27].

Evidently the effectiveness of shaping professional and terminological competence is largely determined by the students' motivation for perception and processing, active search and systematization, self-development and creative approach in mastering professional terminology. The realization of this purpose is facilitated by the introduction of innovative, interactive and imitationgame forms of learning, based on the principles of clearness, visualization, dialogue, gamification, individual and competent approaches. Advantages of use interactive innovative methods are increasing of students' motivation to study professional terminology, compliance with the individual rate of professional information processing, identification of specificity and semantic-andetymological relations between the term elements, simplification of semantic and etymological analysis of terms and specificity of word formation, improving the skills to work with reference literature by specialty.

Among the various tools of creative study of terminology there is the looping technology that assumes a repeated return to what has been learned in order to consolidate the already tried and tested terminology [28]. In course of the laboratory studies and practical preparation it is need to take advantages the technologies modeling of professional orientated situations which ensure the improvement of future the specialists' professional speech and communicative skills.

Advisably to usage mobile learning technologies and actively implement mobile apps to identify plants, to study Latin, chemical structure and properties of substances, anatomy and whatever, during field practice and independent work of future biology teachers. These apps can significantly simplify the completion of individual search tasks by students for work off the professional terminology [29].

In course of lectures and laboratory-and-practical studies can be effective such interactive methods as the method of word-and-clouds (word-tags, word clouds), mind maps (mental maps), semantic-and-etymological analysis of the term and its word-formation, synonymically-and-antonymically-and-paronymic method (which eliminates in future confusion in identification of the various terms) and others.

It is the simulation method that can ensure efficiency and effectiveness of terminological work. Modeling refers to the process of creating models that mimic biological objects or processes. The result can be represented in material or informational form, as for instance in the form of dummy, text, spreadsheet, graphic, computer model, etc. The main functions of the modeling method in the shaping of students' professional and terminological competence are heuristic and generalizing ones.

In order to gain a clear understanding and systematization of terms on a particular topic, it is advisable to use schematic-and-sign visualization, which allows attract students' eidetic and visual memory. Mastering a terminosystem on a specific topic or module with help of such type visualization enables reveal the structure of the concept being studied and the essential connections between the components [30]. As a practice 
shows, characterizing the terms and the relations between them can be efficiently with use the following means and tools:

- Intelligence Cards (MindMap).

- Venn diagrams - techniques of graphical presentation of information during comparing two or more concepts or ideas that are simultaneously both similar and different.

- Schemagraphics - a step-by-step investigation of the concept in a diagram form.

- Concept tables comparing terms by the same criteria or attributes.

- "T-diagrams" - a way of displaying and organizing the results of the term's analysis taking into account its properties.

- "Bloom's Chamomile" (chamomile of questions) a graphic representation of phased study of a certain term.

- The schemes with brackets for the grading of the term on a much larger number of grounds (see Fig. 4).

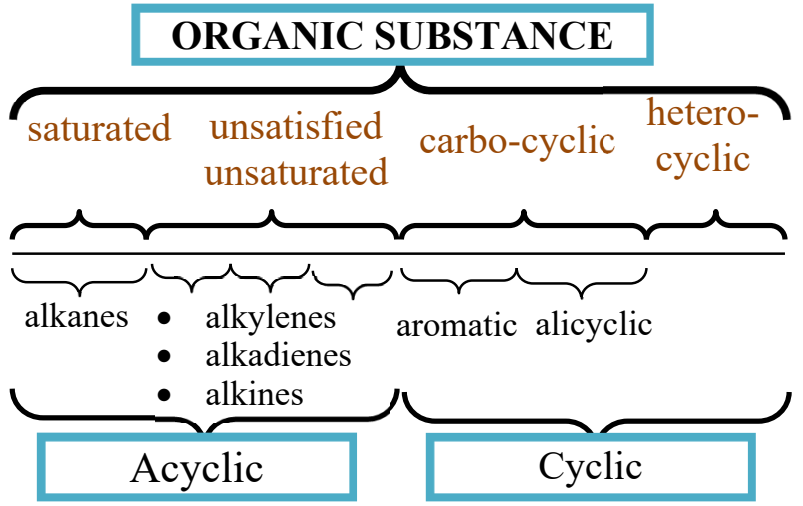

Fig. 4. The schemes with brackets.

- The tree of graphs or trees of concept.

- Structural diagrams with rectangular blocks, rhombuses and arrows denoting parts of phenomena and possibility of alternative transitions, and connections of parts.

- The infographics - schematic depictions of the concepts' system and connections between them via graphical means.

- The structural-and-logical schemes of topics or sections $[31 ; 32]$.

The application of these tools is the most important moment for situations of perception, design and creative transformation of professional terms by future biology teachers. In this case, the introduction and assimilation of procedures for schematization and operating on with schemes is a key in shaping of the students' professional and terminological competence [33]. The only fundamental drawback of the terminosystem's schematicand-sign visualization tools is the considerable complexity in their production and working off.

It should be emphasized that with the accumulation of the scientific terminology by future biology teachers would do well to conduct the timely control of learned terms. Didactic cards that combine several techniques of terminological work, as well as biological or terminological dictations, can be used to test knowledge.
Therefore, it can be convinced that profound mastery of concepts is possible only if students master the specialty language in a timely and systematic manner, learn special terms during purposefully organized activity. Thus, the activity approach provides for the circumstances in which a student can independently identify the common and particular, can classify, conduct and organize observations of the studied phenomena and objects [34]. As a result of the application of a number of didactic means, purposeful and gradual shaping of future biology teachers' professional and terminological competence is possible.

\subsection{Overview the content of the distance course "Latin. Botanical Terminology"}

The distant special course "Latin. Botanical terminology" is intended for students of specialty 014 Secondary education (Biology and human health) of Kryvyi Rih State Pedagogical University [35]. This course aims to increase students' awareness in biological terminology, contributes understanding of the relations between Latin and Ukrainian, and facilitates the terminosystem's assimilation (it shown in Fig. 5).

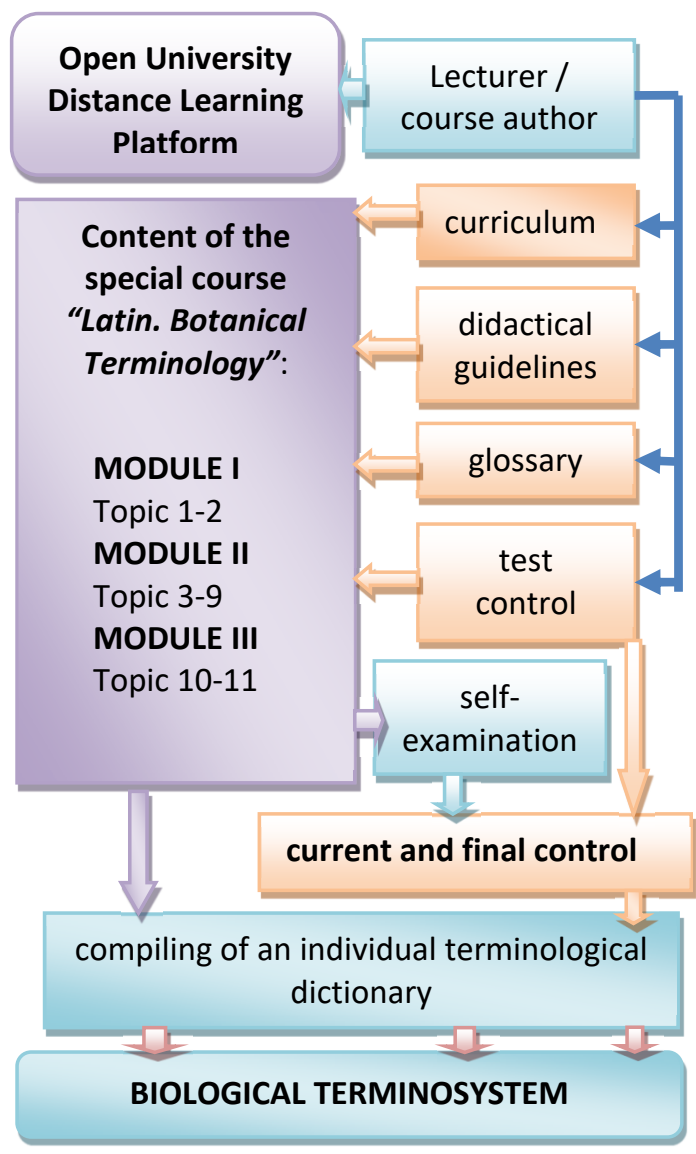

Fig. 5. The course of "Latin. Botanical Terminology" structure.

One of the main objectives of the course at the Sciences Faculty is to prepare the future teachers, based on knowledge of Latin, to perceive special courses (the professional cycle subjects) and to understand of international scientific terminology. As experience has 
shown, familiarity with Latin develops logical thinking, enhances linguistic culture and promotes widening the students' general outlook.

During the formation of the special course's content we proceeded from the assumption that the teacher's professional activity requires not only professional skill but also a broad general subject knowledge (professional competence), literate oral and written speech. The modern high school aims at forming not only the skills of intellectual work, but the creative abilities of the future specialist. The ability to use the acquired knowledge creatively is a social value because it helps the specialist to perform social and professional functions, quickly adapt to new economic conditions, promotes a flexible transition from one activity to another. In this viewpoint the professional and terminological competence is determined by the literacy of the use of subject professional terminology in professional activity. These qualities are very important both for the future biology teacher and for any person in the sustainable development era.

Let's consider the main content of the special course "Latin. Botanical Terminology".

Module I. History of the biological terminology and nomenclature formation.

Topic 1. The concepts of "scientific term" and "terminoelement".

Topic 2. Binary Nomenclature: purpose and history of formation.

Module II. Principles of the phytonomens construction.

Topic 3. The informative content of the Latin names of living organisms.

Topic 4. Methods of formation of the Latin species epithets.

Topic 5. Botanical Eponyms: Classification and Meaning.

Topic 6 . The etymology of plant names.

Topic 7. Widespread plants species names. Ukrainian and Latin phytonomens.

Topic 8. Latin names of plant communities.

Topic 9. Sense of the main term elements as components of word-building.

Module III. Binary Scientific Nomenclature and International Nomenclature Code.

Topic 10. International Code of Scientific Nomenclature:

ICBN (International Botanical Nomenclature Code),

ICNCP (International Crop Nomenclature Code),

ICZN (International Zoological Nomenclature Code),

ICNB (International Bacterial Nomenclature Code).

Topic 11. Rules and principles of the international binary nomenclature.

Reasoning from the specificity of the study of Latin as the basis of biological terminology, during the special course, the focus attention is to the terminological sense of words, the investigation of Greek-Latin terminosistem, as well as the study of etymology and semantics of biological concepts. Among the varieties of tasks for the shaping of students' professional and terminological competence we used such as: the task of mastering terminoelements and basic phytonomenes, ones of compiling comparative and summarizing tables, exercises on the correct pronunciation, stress, the definition of terminological bases as well as of prefixes, suffixes, and flections of words; creating degrees of comparison of adjectives, numeral terminoelements, etc.

In the end, it contributes to the shaping and development of the future biology teachers' professional and terminological competence.

\subsection{Use of the National Biodiversity Information Network in terminological work with students}

As noted above, one of the goals of a sustainable development society is to conserve our planet's biodiversity. According to the Biological Diversity Conservation Concept of Ukraine for 2005-2025 [36], it is envisaged for the current period to ensure the implementation series of measures. This means the reproduction of plant and animal species populations, their natural communities and ecosystems, improvement of the infrastructure which necessary for the Program implementation, as well as its goals adjustment and do control over their decision. Successful implementation of these tasks requires continuous monitoring of species diversity provided by the Ukrainian Biodiversity Information Network - UkrBIN [37].

$U k r B I N$ is a pilot project, the only platform in Ukraine for free access to biodiversity accumulation and exchange. Anyone can join to give a leg up the nationwide database on biodiversity, distribution and abundance of plant and animal species in Ukraine and the world, at the same time to help preserve the natural potential of our planet.

It should take into account the data collected under the $U k r B I N$ project are part of the largest international biodiversity data registers of the Catalog of Life and the Global Biodiversity Information Facility (GBIF) [37]. $U k r B I N$ has a user-friendly interface, an open database that shows the presence and abundance of species using data from downloaded taxa lists.

The main features of the $U k r B I N$ database that can be used in the educational process of preparing a future biology teacher are following:

- digitalization of own or common observations (uploading photos and descriptions);

- tracking own annotated watch list;

- searching a photo to identify plants or animals;

- finding out the trophic connections;

- studying of dynamic maps and graphs;

- viewing the phonograms (annual phonograms, frequency of occurrence data and species abundance, and whatever);

- browsing by region statistics and annotated lists (by country, region or area) with use queries and filters;

- viewing by map of the species, genera and families distribution;

- using rapid field determinants for the study of flora and fauna, designed for teachers, students, ecologists, nature conservationists and amateur naturalists.

The participation of future biology teachers in expanding the $U k r B I N$ database increases their motivation 
in the development of professional subjects and field practice, introduces them to the problems of biodiversity conservation for the goals of society's sustainable development. Not only this resource allows viewing the database, but also adding one's own observations, commenting, participating in the forum. It helps to develop communication skills and expand the individual active terminological dictionary of a future specialist.

\section{Conclusions}

The problem of conservation and increase of the biodiversity of our planet deserves special attention among the leading goals of the sustainable development of society. This difficult issue can be solved by way of the preparation of qualified biology teachers who have master a high level of terminosystem and binary nomenclature of modern science.

Professional and terminological competence is defined as the formed ability of specialists to competently and expediently use professional terms in their professional activity. The main aspects and categories that characterize the professional and terminological competence of future biology teachers are the terminology and nomenclature and, accordingly, the term and nomen. The terminosystem unit is a term denoting a certain abstract concept and categories. The unit of nomenclature is nomen that is special terms-name meaning single, and specific concepts. The nomenclature is seen as a component of the terminosystem, or as an intermediate link between terms and their own words. The biological nomenclature is represented by numbers (species binomials) that correspond to the extent of the conditional division of the organic world into taxa. The nomenclature ensures the uniqueness of the nominees in biological research. We believe that nomenclature is a specific part of biological terminology. The term elements are common to terminology and nomenclature.

An essential feature of Latin nomens, approved by the relevant codes of nomenclature, is that they have international recognition, facilitate communication between scholars and promote the science development. The distant special course "Latin. Botanical terminology" has intended for study of the biological terminology and shaping the future biology teachers' professional and terminological competence.

Understanding the essence and structure of professional and terminological competence is the initial stage for design a methodology for its formation during the future biology teachers' vocational training process. Among the didactic means for the shaping of professional and terminological competence are the following: methods and techniques of terminological work, active individual terminological dictionary, independent work on a specialty, innovative, interactive and imitation-game forms of learning, based on the principles of clearness, visualization, dialogue, gamification, individual and competent approaches, as well as a looping technology, modeling of professional orientated situations, mobile learning technologies, interactive and simulation methods, schematic-and-sign visualization.
A significant impact on the formation of students' professional and terminological competence is provided by work with the Ukrainian Biodiversity Information Network - UkrBIN. This resource makes it possible to observe and record, distribute among naturalists, discuss, track and replenish data on the biodiversity of our planet

On the basis of mastering the capacitive system of term elements it is possible to form an individual active terminological dictionary of a future specialist. This, in turn, will provide high-quality preparation of students for life in a sustainable development era.

\section{References}

1. A. Yu. Yakymchuk, Derzhavna polityka staloho zberezhennia bioriznomanittia Ukrainy (State Policy for Sustainable Biodiversity Conservation of Ukraine). (NUVHP, Rivne, 2014), p. 477, http://ep3.nuwm.edu.ua/3195/1/128zah.pdf. Accessed 4 Jan 2020

2. S. Shabanov, F. Quliyev, Expert approach to statistical assessment of education quality: The case of Azerbaijan. Paper presented at the 10th International Conference on Application of Information and Communication Technologies (AICT), 1-3 October 2016

3. Postanova Kabinetu Ministriv Ukrainy No. 439. 12.05.1997. Pro Kontseptsiiu zberezhennia biolohichnoho riznomanittia Ukrainy (Resolution of the Cabinet of Ministers of Ukraine No. 439. 12.05.1997. About the Concept of Biodiversity Conservation of Ukraine), https://zakon.rada.gov.ua/laws/show/439-97\%D0\%BF. Accessed 4 Jan 2020

4. T.O. Butenko, Dissertation, Vinnytsia Mykhailo Kotsiubynskyi State Pedagogical University, 2011

5. O.Ye. Hrydzhuk, Fakhova terminolohiia (Professional terminology) (Novyi Svit, Lviv, 2000), p. 404

6. L.V. Baranovska, Dissertation, National Pedagogical Dragomanov University, 2005

7. V.A. Demin, Professionalnaya kompetentnost spetsialista: ponyatie i vidyi (Professional competence of a specialist: concept and types). Monitoring of the educational process 4, 34-42 (2000)

8. O.O. Veklych, Struktura suchasnoho mekhanizmu ekolohichnoi kompensatsii (mekhanizmu ekokompensatsii) (Structure of the modern mechanism of environmental compensation (of the ecocompensation mechanism). An efficient economy 8 (2019). doi:10.32702/2307-2105-2019.8.3

9. L.S. Hryniv, Transdisciplinary approach to sustainability: new models and possibilities, in Ecological Economics and sustainable forest management, ed. by I.P. Soloviy, W.S. Keeton (UNFUP, Lviv, 2009), pp. 85-97 
10. I.M. Syniakevych, Ekonomika pryrodokorystuvannia (Economics of nature management) (ZUKTs, Kiev, 1996), p. 156

11. A.S. Tulupov, Dissertation, State University of Management, 2013

12. A.V. Lemov, Dissertation, Mordovian State University named after N.P. Ogarev, 2000

13. V.M. Leychik, Terminovedenie: predmet, metodyi, struktura (Terminology: subject, methods, and structure). (Librokom, Moskva, 2007), p. 256

14. O.I. Moiseev, O yazyikovoy prirode termina (On the linguistic nature of the term), in Linguistic problems of scientific and technical terminology (Nauka, Moscow, 1970), pp. 127-138

15. N. Shvets, Spivvidnoshennia poniat "termin" i "nomen" (na materiali anhliiskykh ikhtionimiv) (The relation between the concepts "term" and "nomen" (based on English ichthyonyms)). Psykholinhvistyka - Psycholinguistics 8, 167-171 (2011)

16. H.F. Rakshanova, Dissertation, Cherkasy State Technological University, 2004

17. Y.V. Fedorova, Funktsyonyrovanye obshchenauchnoi leksyky v nauchnotekhnycheskom tekste (Functioning of general scientific vocabulary in scientific and technical text). High School Scientific Reports: Philological Sciences 4, 59-65 (1986)

18. V.V. Pererva, Professional training of a future biology teacher using M-learning technology. Engineering and Educational Technologies 7(3) (2019). doi:10.30929/2307-9770.2019.07.03.07

19. L.V. Viktorova, Dissertation, Chernihiv State Pedagogical University named after T.G. Shevchenko, 2009

20. I.V. Vlasiuk, Dissertation, Vinnytsia Mykhailo Kotsiubynskyi State Pedagogical University, 2015

21. O.I. Pavlova, Terminy, profesionalizmy i nomenklaturni znaky (do problemy klasyfikatsii spetsialnoi leksyky) (Terms, professionalism and nomenclature signs (to the problem of the special vocabulary classification)). Visnyk Natsionalnoho universytetu "Lvivska politekhnika": Series "Problems of Ukrainian Terminology" 620, 49-54 (2008)

22. B.N. Holovyn, R.Yu. Kobryn, Lynhvystycheskye osnovy uchenyia o termynakh (Linguistic basis of the terms' doctrine). (Vysshaya shkola, Moskva, 1987)

23. P.M. Ustymenko, D.V. Dubyna, Kodeks fitotsenotaksonomichnoi nomenklatury Ukrainy (proekt) (Code of phytocenotaxonomic nomenclature of Ukraine (project)). Ukrainskyi botanichnyi zhurnal 72(2) (2015). doi:10.15407/ukrbotj72.02.103

24. J. Winston, Twenty-First Century Biological Nomenclature - The Enduring Power of Names. Integrative and Comparative Biology 58(6) (2018). doi:10.1093/icb/icy060
25. I.V. Moroz (ed.), Zahalna metodyka navchannia biolohii (General methodology of teaching biology). (Lybid, Kyiv, 2006), p. 592

26. N.A. Menchinskaya, Puti realizatsii v psihologii printsipa edinstva vospitaniya i obucheniya (Ways to implement in psychology the principle of the unity of education and training). Soviet pedagogy 9, 8-17 (1975)

27. T. Grynko, O. Krupskyi, M. Koshevyi, O. Maximchuk, Modern concepts of financial and non-financial motivation of service industries staff. Journal of Advanced Research in Law and Economics 8(4(26)), 1100-1112 (2017)

28. H.F. Rakshanova, I.L. Nazarenko, Formuvannia fakhovoi terminolohichnoi kompetentnosti $u$ studentiv (Forming of the students' professional terminological competence). Philological studios 17, 249-260 (2018)

29. S. Pudova, Using a Mobile Phone in The Learning Process. Physical and Mathematical Education 2(16) (2018). doi:10.31110/2413-1571-2018-016-2-018

30. V.T. Rozin, Chto takoe pamyat? (What is memory?) Voprosy psikhologii 1, 78-89 (2001)

31. S.H. Kobernik (ed.), Metodyka vykladannia heohrafii $v$ shkoli (Methods of teaching geography at school). (Lybid, Kyiv, 2000), p. 320

32. I.S. Ladenko, Intellekt $i$ logika (Intelligence and logic). (Izd-vo Krasnoiar. un-ta, Krasnoyarsk, 1985), p. 144

33. O.S. Anisimov, Metodologicheskaya kultura pedagogicheskoy deyatelnosti $i$ myishleniya (Methodological culture of pedagogical activity and thinking). (Ekonomika, Moskva, 1991), p. 415

34. O.O. Lavrentieva, Methodological approaches to vocational training organization, in Management of higher educational quality: problems and prospects. London (2017)

35. Latyn. Botanichna terminolohiia (Latin. Botanical terminology), E-learning course (2020), https://moodle.kdpu.edu.ua. Accessed 4 Jan 2020

36. Kontseptsiia zahalnoderzhavnoi prohramy zberezhennia bioriznomanittia na 2005-2025 roky (The concept of a national biodiversity conservation program for 2005-2025) (2004), https://www.kmu.gov.ua/ua/npas/9110364. Accessed 4 Jan 2020

37. UkrBIN, Ukrainian Biodiversity Information Network [public project \& web application]. UkrBIN, Database on Biodiversity Information (2017), http://www.ukrbin.com. Accessed 4 Jan 2020 